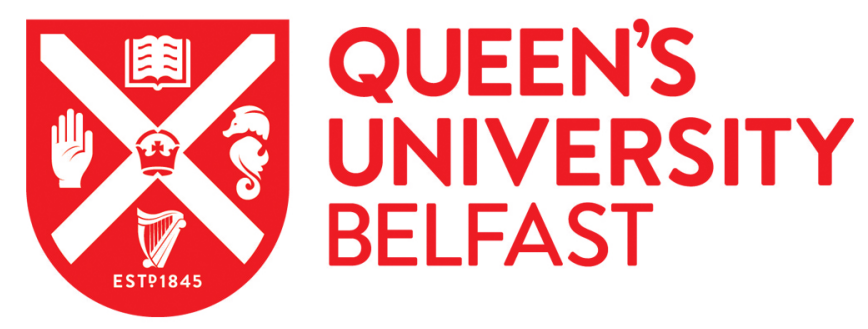

\title{
In a City of Mills and Canals: Mortality among Pre-teen and Teenage Irish Workers in Mid-Nineteenth-Century Industrial Lowell, Massachusetts
}

Murphy, E., Donnelly, C., \& McKean, D. (2019). In a City of Mills and Canals: Mortality among Pre-teen and Teenage Irish Workers in Mid-Nineteenth-Century Industrial Lowell, Massachusetts. Childhood in the Past, 12(2), 117-128. https://doi.org/10.1080/17585716.2019.1638557

Published in:

Childhood in the Past

Document Version:

Peer reviewed version

Queen's University Belfast - Research Portal:

Link to publication record in Queen's University Belfast Research Portal

Publisher rights

(c) Informa UK Limited, trading as Taylor \& Francis Group and the Society for the Study of Childhood in the Past 2019.

This work is made available online in accordance with the publisher's policies. Please refer to any applicable terms of use of the publisher.

\section{General rights}

Copyright for the publications made accessible via the Queen's University Belfast Research Portal is retained by the author(s) and / or other copyright owners and it is a condition of accessing these publications that users recognise and abide by the legal requirements associated with these rights.

Take down policy

The Research Portal is Queen's institutional repository that provides access to Queen's research output. Every effort has been made to ensure that content in the Research Portal does not infringe any person's rights, or applicable UK laws. If you discover content in the Research Portal that you believe breaches copyright or violates any law, please contact openaccess@qub.ac.uk. 
In a City of Mills and Canals: Mortality among Pre-teen and Teenage Irish Workers in Mid-Nineteenth-Century Industrial Lowell, Massachusetts

Eileen Murphy ${ }^{1^{*}}$, Colm Donnelly ${ }^{2}$ and Dave McKean $^{3}$

1 Archaeology and Palaeoecology, School of Natural and Built Environment, Queen's University Belfast, Belfast BT7 1NN, Northern Ireland. Email: eileen.murphy@qub.ac.uk. *Corresponding author.

2 Archaeology and Palaeoecology, School of Natural and Built Environment, Queen's University Belfast, Belfast BT7 1NN, Northern Ireland. Email:

c.j.donnelly@qub.ac.uk

3 Independent researcher, Lowell, Massachusetts. Email: dadumc@comcast.net

\section{Biography statements}

Eileen Murphy is Professor of Archaeology in the School of Natural and Built Environment, Queen's University Belfast. She is a bioarchaeologist with particular interest in past funerary practices and her publications include Children, Death and Burial: Archaeological Discourses (2017, edited with M. Le Roy). She has undertaken a major study of the grave memorials of Lowell's nineteenth-century Irish settlers.

Colm Donnelly is the Director of the Centre for Archaeological Fieldwork in the School of Natural and Built Environment, Queen's University Belfast. His research focuses on the history, architecture and archaeology of Late Medieval to Early Modern Ireland. He led a three-season transatlantic excavation and education programme between the University of Massachusetts in Lowell and Queen's University Belfast. This involved the excavation in Lowell of a site associated with Irish settlers from the 1840s, and the excavation in County Tyrone of a homestead of one of those settlers.

Dave McKean is a native of Lowell, an avid local historian, and archivist with St Patrick's Church in the Acre. He has been fully involved with the UMASS Lowell and 
QUB research activities in the city. Dave is the author of The Cross and the Shamrock: The Art and History of St. Patrick Cemetery, Lowell, MA (1997), Lowell Irish (2016) and The Days that Went Before Us (2018).

\begin{abstract}
Lowell, Massachusetts, is considered as the birthplace of the industrial revolution in the United States during the early nineteenth-century. Established in 1821 by a group of Bostonian entrepreneurs, the new textile factories harnessed the waters of the Merrimack River to power their waterwheels using a system of canals, dug and maintained by labourers. While this work employed many local Yankees, it also attracted groups of emigrant Irish workers from Boston, a process that continued into the middle of the century, particularly in the wake of the Great Irish Famine (18451852). In time, the Irish would begin to replace the Yankee female workers in the textile mills, the latter having grown increasingly discontent in the face of deteriorating working conditions. The Irish, in contrast, provided employers with a relatively cheap and easily satisfied workforce.
\end{abstract}

We are fortunate that two volumes known as the Hanavor Burial Records exist that provide a window into the lives and deaths of the early Irish settlers in Lowell. Some 1,450 entries dating to the period between 1849 and 1865 provide details of the occupation of the deceased as well as, in many instances, the cause of their death. This study will focus on the role of Irish pre-teen and teenage workers; their age-atdeath profile, the nature of the work in which they were engaged, and the causes of their death will all be examined to explore the quality of their lives in this industrial powerhouse.

Key words: industrial revolution, child labour, mill working, lung complaints, tuberculosis, accidents

\title{
Introduction
}

Lowell, Massachusetts, is considered the birthplace of the industrial revolution in the United States during the early nineteenth-century (Fig. 1). It was selected in 1821 as a suitable location for a new textile milling complex by a group of Bostonian entrepreneurs who recognised that the waters of the Pawtucket Falls on the 
Merrimack River in East Chelmsford could be used to power the waterwheels for factories. This resulted in the creation of the Merrimack Manufacturing Company and the construction of new mills and associated buildings as well as housing for the mill workers, while a network of canals was also excavated to bring the river water to the mills' waterwheels. In 1826 the new mill village was named Lowell and became separated from Chelmsford (Mitchell 2006, 10-11).

In its early days Lowell was often described as one of the wonders of the modern world and was an obligatory stop for Europeans touring the United States. It was contrasted with the infamous industrial cities of the Old World and most visitors were dazzled by the sheer scale of its industry; massive five and six storey brick textile mills lined the Merrimack River for almost a mile against a backdrop of scattered farmsteads. Added to this was a complex network of canals which, by 1850 , extended for some six miles through the city (Dublin 1992, 15). The initial excavation work on the canals in 1822 employed many local Yankees but this could not fulfil the need for a large pool of unskilled labourers and groups of emigrant Irish workers were also attracted from Boston. While Irish people had been present in East Chelmsford before then, this is considered the start of the major Irish influx to the Lowell area. As more and more Irish workers arrived they based themselves in what were referred to as the 'paddy camps' on the edge of the new town in an area known as the Acre, which by 1830 had become a permanent fixture of the town. Throughout the early 1830 s and 1840 s significant numbers of Irish emigrants were attracted to Lowell but the numbers greatly increased in the wake of the Great Irish Famine (1845-1852) and this had a major impact on the profile of those employed in the mills (Mitchell 2006, 14-15, 33, 85, 89).

In the early days many of the mill workers were young Yankee women from neighbouring farms who wished to seek independence and employment in their midteens and early twenties, prior to marriage (Dublin 1993, 32). Lowell was designed to appeal to these respectable middle-class women and their families and the boarding houses in which they lived operated under strict rules overseen by a matron (Gordon 2002, 61-62). Initially the mill owners adopted a paternalistic approach towards their employees and a conscious effort was made not to emulate the social ills of the industrial revolution in England. Publicity emphasised the good working conditions, 
short-term nature of employment, and the quality of the workers (Dublin 1993, 77). Foreign visitors to the factories, including Charles Dickens who visited in 1842, were impressed by the cleanliness and health of the workers as well as the conditions in which they worked, contrasting them to the experiences of their native countries (Kenngott 1912, 13-14). It is interesting that Dickens explicitly noted: 'There are a few children employed in these factories, but not many. The laws of the state forbid their working more than nine months in the year and require that they be educated during the other three' (Dickens [1842] 1913, 56).

Profit, rather than the social improvement of their workers, remained the main interest of the mill owners, however, and proposed wage cuts, increases in boarding fees and deteriorating working conditions, resulted in sustained protests and strike action by the mill girls throughout the 1830s and 1840s (see Robinson 1898, 83-86; Dublin 1993, Chapters 3 and 4). A response to a petition in 1845 resulted in a state investigation led by William Schouler, editor of the Lowell Courier. During a testimony the complainants argued for a ten-hour working day for the good of their health, also stating that breaks between meals were too short and the air was impure from cotton dust and smoke from the oil lamps used to light the rooms (Dublin 1993, 114). This was also a period of migration with many Yankee families moving to the Midwest and the mill owners were increasingly forced to look elsewhere for their workers (Kenngott 1912, 27). The mill industry in Lowell had expanded very quickly and the numbers of mills there by 1850 was double the 20 that existed in 1836 . The population had risen from 16,000 in 1836 to at least 33,000 by 1850 and Lowell was considered hugely overcrowded at this time (Dublin 1992, 39). Mill records indicate that by 1850 a much smaller proportion of workers were local women, with the majority of the workforce comprising immigrants (Dublin 1993, 133-135, 138), and from around 1845 onwards, and for the next 20 years or so, the Irish became the main labour force in Lowell's mills (Kenngott 1912, 27). Those Irish arriving in Boston in the mid-century were in dire economic need and were happy to find employment in the mills, regardless of conditions. The wages were better than those earned in domestic service or outdoor labour and children could be employed, thereby increasing a family's income (Dublin 1993, 140). By 1850 the company paternalism that characterised the early days of the mill industry in Lowell had all but disappeared and maintaining profits in the face of increasing competition was now 
clearly the main concern (Dublin 1993, 136, 143). Documentation associated with mills in the 1850s, however, indicates that the Irish were held in poor regard by mill owners, compared to native-born employees. They were prevented from using subsidised boarding houses, received less pay and experienced worse working conditions in physically segregated rooms within the mills (Dublin 1993, 153-157).

We are fortunate that two volumes known as The Hanavor Burial Records exist, curated at St. Patrick's Church, Lowell, that provide a window into the lives and deaths of some of the early Irish emigrants who had moved to Lowell in the aftermath of the Great Famine in Ireland. The records were kept by officials associated with St Patrick's Roman Catholic burial ground in the town, and of the 8,166 records, some 1,423 entries, dating to the period between 1849 and 1865, provide details of the age-at-death and occupation of the deceased as well as, in many instances, the cause of their death. In this study we will use this resource to attempt to ascertain the role that Irish pre-teens and teenager immigrants played in the industrial workings of Lowell. We will examine the effect that such labours may have had on the quality of their lives as well as the impact on their health status.

\section{Irish Workers in Lowell}

It is evident from the age profile of the 1,423 records of individuals in the burial records with details of occupation that many survived to old age but a sizeable proportion died as young adults in their 20 s and 30 s (48.0\%). This would suggest that life was hard for the early Irish immigrants. The current study will, however, focus on the 169 workers (12.0\%) who died as pre-teens or teenagers. The issues surrounding differences between social and biological age have been well rehearsed (e.g. McKerr et al. 2009, 114-116) and this paper will focus on those aged less than 20 years whose bodies were still growing and developing. It should be appreciated, however, that older teenagers would very probably have been viewed as young adults within contemporary society.

\section{Demographic Profile}

The age-at-death profile for the entire population indicated that females had a greater likelihood of dying at a young age than males. This was particularly evident for the youngest group ( $F-15.4 \% ; 120 / 780 ; M-7.6 \% ; 49 / 643)$, but also followed 
through for women in their twenties ( $F-31.9 \% ; 249 / 780 ; M-26.0 \% ; 167 / 643)$ and thirties ( $F-20.3 \% ; 158 / 780 ; M-17.1 \% ; 110 / 643)$ before the trend reversed for older groups in which greater proportions of males died. At a first glance it might be thought the trend was related to issues associated with pregnancy and childbirth, especially for the women in their twenties and thirties, but this was only listed as a cause of death for one nineteen-year-old woman who died of an infection after delivery and it does not account for the peak in the youngest age group. It is also possible the age-at-death profile is simply reflecting the demographics of mill workers. As discussed above, at this time the majority of these would have been Irish immigrants and the mill appears to have been particularly appealing to unmarried young adult Irish women (Mitchell 2006, 89-90).

All individuals included in the study were workers and, since this would have been a major component of their daily lives, it seems feasible that premature death was connected to their work, although undoubtedly the nature of their living conditions would have also contributed. Concerns about child labour were raised as early as 1832 with The New England Association of Farmers, Mechanics and Other Workingmen lamenting that most factory owners only allowed children 'to obtain an education ... on the Sabbath, and after half past eight o'clock, of the evening of other days', which they viewed as having a negative impact on their development and general well-being (Brown 1996, 161). A substantial body of legislation issued by the state of Massachusetts exists in relation to child labour and nineteenth-century Lowell. An act passed in 1836 focused on the employment and education of working children and required those younger than 15 years, employed in manufacturing establishments, to be provided with three months of schooling. In a further act in 1842 the hours for children under twelve years was reduced to ten hours per day. Legislation related to schooling was amended in 1849, when the requirement was 11 weeks, later amended to 18 weeks in 1852. It is considered that these laws were hastily constructed and were designed to appease labour agitators rather than genuinely address problems with the employment situation (Whittelsey 1901, 9-10).

The legislation changed in 1866 so that: 'No child under the age of ten years shall be employed in any manufacturing establishment in this state, and no child between the age of ten and fourteen years shall be so employed' unless they had attended school 
for at least six months in the year prior to employment. They were then required to attend school for six months each year thereafter. It also ruled that children under fourteen years were not to work longer than eight hours per day. A replacement act the following year forbade the employment of any child under ten years in any manufacturing or mechanical establishment. Children younger than fifteen years were only permitted to work if they had attended school for at least three months during the preceding year, and for no more than sixty hours per week. Whittelsey $(1901,12)$ observed, however, the existence of documentary evidence indicative that all of these rulings were violated, while she found no evidence suggestive that any offending employers were ever prosecuted. The implication from these pieces of legislation is that children aged between ten and fourteen years formed a consistent component of the workforce during this era despite the apparent concerns for their welfare evident in the legislation. The absence of evidence for working children aged less than 11 years in the burial records may be indicative that younger children were not employed in factories prior to the formalisation of this ruling in the 1866 legislation.

When the age-at-death profile of the youngest group is scrutinised, it is evident that the vast majority of young female $(90.8 \% ; 109 / 120)$ and male $(93.9 \% ; 46 / 49)$ workers died at the age of fifteen years or older (Fig. 2). The occurrence of 11 working girls and three boys aged fourteen years or less in the death records, however, is a clear indication that younger children were employed, as suggested in the legislation. The youngest workers recorded in these records were both aged eleven years. Little Elen Scanlin worked as a machine operative in a mill but her cause of death is not listed. Lawrence Gray also worked in a mill and his cause of death is recorded as 'killed', so presumably he died as a result of an accident. Nine of these eleven girls worked in a mill, and former mill girl, Harriet $\mathrm{H}$. Robinson's $(1898,12-13)$, reminiscences of the 1840 s refer to Irish children in the mills:

'The first Irishwomen to work in the Lowell mills were usually scrubbers and waste-pickers. They were always good-natured, and when excited used their own language; the little mill-children learned many of the words (which all seemed to be joined together like compound words), and these mites would often answer back, in true Hibernian fashion. These women, as a rule, wore 
peasant cloaks, red or blue, made with hoods and several capes, in summer (as they told the children), to "kape cool," and in winter to "kape warrum." They were not intemperate, nor "bitterly poor." They earned good wages, and they and their children, especially their children, very soon adapted themselves to their changed conditions of life, and became as "good as anybody".

In his survey of mill statistics in 1845 Rev Miles asked the surveyed corporations about the numbers of children they employed aged less than fifteen years, and small numbers were reported in the cotton mills - Lawrence (10), Suffolk (8) Merrimack (5), Tremont (3), Appleton (1) and Boott (0). He commented that the Print Works and Carpet Mills contained a larger proportion of children but did not provide details (Miles 1845, 192-193). The statement provided by J. Clark, superintendent of the Merrimack Corporation, provided some explanation of the practice stating that: 'Our rule is, to employ no child under fifteen years of age'. He goes on to state that all such applications are referred to him with the majority rejected outright. Exceptions were made for instances when the child's mother or sisters (when the parents were dead) worked in the mill, and that on average they would have three or four such cases (Miles 1845, 184). The rise of the immigrant workforce in the mills from 1845 onwards appears to have been associated with an increase in child workers. The proportions of those providing proof of school attendance for the Hamilton Company in Lowell, as recorded in their register books, increased from $2.3 \%$ of workers in 1836 to $6.5 \%$ in 1860 (Dublin 1993, 140), although it is also possible that this is due to the changes in legislation discussed above that required documentation of school attendance.

When we look at the sex ratio of the pre-teens and teens it becomes apparent that girls greatly predominate in the burial records, comprising $71.0 \%(120 / 169)$ of the group. These proportions infer that working girls were more likely to die young than their male counterparts (see Fig. 2). A greater proportion of girls $(9.2 \% ; 11 / 120)$ than boys $(6.1 \%$; $3 / 49)$ died at the age of 14 years or younger, and this trend continued across the ages of 15-18 years. The situation is dramatically reversed, however, for the age of 19 years when the proportion of male $(40.8 \%$; $20 / 49)$ deaths was notably greater compared to their female $(24.2 \% ; 49 / 120)$ counterparts. 


\section{Child Labour}

\section{Activities}

It is evident that most of the female pre-teens and teens had jobs in mills, including as machinery operatives $(86.7 \% ; 104 / 120)$, with a lesser number working as housemaids (13.3\%; 16/120) (Fig. 3). Of the girls aged fourteen years and younger, the majority worked in mills $(81.8 \%$; 9/11), although thirteen-year-old Elizabeth White and fourteen-year-old Marget Dolan were both employed as housemaids. The young male workers had a greater variety of jobs, but almost all were employed as labourers $(49.0 \% ; 24 / 49)$ or in the mills $(43.0 \%$; 21/49). The three boys aged fourteen or less had worked in a mill (Lawrence Gray aged 11 years), as a labourer (John Tearney aged 14 years) and in a dye house (Cornelius Onaill aged 14 years).

Historical accounts of children's work (10-15 years) in mills suggests that, while they were required to remain in the mill for a full twelve-hour day, their tasks occurred in bursts of activity that were punctuated by breaks. Examples of such tasks included tending the carding machines (Lapboys) or replacing bobbins full of spun yarn on the machines with empty ones (Bobbin boys and girls - doffers) (Dublin 1993, 64, 69). Yankee mill worker Harriet Robinson $(1898,30)$ started work in a mill in 1836 at just ten years of age to help her mother financially and she describes her work as a doffer:

I can see myself now, racing down the alley, between the spinning-frames, carrying in front of me a bobbin-box bigger than I was. These mites had to be very swift in their movements, so as not to keep the spinning-frames stopped long, and they worked only about fifteen minutes in every hour. The rest of the time was their own ...

\section{Cause of Death}

Some 105 records contained details of the causes of death for young female workers and it is evident that half $(8 / 16)$ of the housemaids were considered to have died of consumption, with individual cases of eight other conditions recorded (Fig. 4). A similar trend was observed for females who worked in the mills, but although consumption was listed by far as the main killer at $64.0 \%$ (57/89), other lung disease, including pleurisy, lung fever, congestion and bleeding lungs were a secondary 
cause of death at $10.2 \%(9 / 89)$. It does need to be appreciated, however, that specific diagnosis of these lung diseases would have been somewhat tenuous since they relied on signs and symptoms rather than later sputum tests and radiographs (see Roberts and Buikstra 2003, 218-219). This was followed by various general infections and inflammations $(5.6 \% ; 5 / 89)$ and a range of specific diseases in lower numbers.

The majority of young male labourers died as a result of accidents $(36.4 \% ; 8 / 22)$ although consumption was the next most frequent killer at $27.4 \%(6 / 22)$ (Fig. 5). Accidents included drowning $(n=3)$ or falling $(n=2)$, while nineteen-year-old Daniel Kelly was recorded as having been 'killed by a bank', which presumably means that it collapsed on top of him, while John McBride, aged fifteen years, died as a result of a cut arm. A range of other diseases also caused the deaths of young male labourers in smaller numbers. Dr John O. Green $(1873,234)$, physician to the Irish canal workers in Lowell in 1822, described how: 'The nature of their employment exposed them to much accident and disease, and my early practice was much among them, night and day'. It is tempting to suggest that the teenage accidents related to drowning and the collapsed bank may have been associated with canal maintenance or construction.

Young male mill workers displayed a similar trend to that of their female counterparts and consumption accounted for around half of the deaths $(52.5 \% ; 10 / 19)$, but accidental deaths were the second highest cause at $15.8 \%(3 / 19)$. No details are provided about the accidents that killed these youngsters - eleven-year-old Lawrence Gray and two seventeen-year-olds, Denis Shea and John Lenard. It is perhaps telling that the names of Lawrence's parents are not listed in the burial records, when this was common practice, and perhaps this child was an orphan who had no option but to work in a mill.

Harriet Robinson (1898, 30-31) worked in a mill as a child in the 1830s and her memoirs describe the experience with happiness, with only the long hours being problematic. When assessing the working conditions in the mills some sixty years later, however, she noted a marked deterioration. She lamented the overcrowded living conditions inhabited by the mill workers and commented on how the cotton 
factories 'used to be well light, ventilated, and moderately heated'. When she visited the dressing room in which she used to work she stated that she 'found the heat so intense that I could hardly breathe'. She observed that the drying of the beams was done by hot air, with the doors and windows kept shut, making the 'atmosphere unfit to breathe' (Robinson 1898, 208-209).

Mitchell's (2006, table 4) survey of disease-related deaths in Lowell found that consumption was the main killer from 1842 to 1846 as well as in 1849 , and was only surpassed by dysentery in 1847 and 1848. The trend was identical for the Acre where the Irish were living, with the exception of 1842, when dysentery was the main killer. During this period the numbers of people affected with tuberculosis appears to have remained relatively constant from 1842 to 1845 but then jumped sharply in 1846 and continued to rise thereafter, in an increase that may have been related to the arrival of the Famine generation of Irish immigrants. Mitchell also suggests that conditions in the mills - the lint-laden air along with the closed windows to ensure the desired levels of humidity - may have been a major contributor (Mitchell 2006, 106). These conditions undoubtedly caused a range of lung problems in mill workers, including the young workers of the current study.

Medical records for Lowell from 1850 to c. 1909 demonstrate that the Irish were the racial group notably prone to death as a result of respiratory conditions, including consumption, diphtheria, croup and pneumonia. This caused the City Physician in 1865 to note in relation to consumption amongst the Irish: '.. the change they make, in leaving domestic employment, going into the mill, where the work and the air are so different, living in crowded, badly ventilated tenements ... account for the great increase of consumption among them' (Kenngott 1912, 90-91). Since tuberculosis was found to have been the main cause of death of young housemaids $(50.0 \%$; $8 / 16)$, and a large proportion of young labourers $(27.4 \% ; 6 / 22)$, it seems that mill conditions were not solely responsible for the spread of the disease, and that their living conditions played a major role. It is perhaps significant though that the other lung diseases, including pleurisy, lung fever, congestion and bleeding lungs $(10.2 \%$; 9/89) were the second most frequent cause of death after consumption among the young female mill workers. As discussed above, specific diagnosis of these various lung diseases may have been problematic but the evidence derived 
from the burial records is certainly suggestive that stress was placed on their respiratory system as a result of their working conditions. This trend was not recorded for young male mill workers for whom the second most common cause of death was accidents $(15.8 \% ; 3 / 19)$, suggesting that young male and female workers engaged in different tasks within a mill. It could be inferred that boys were permitted to engage in perceived hazardous tasks whereas girls were not.

Janet Greenlees (2005) undertook an examination of occupational health and the cotton mills of Lancashire and Massachusetts in the period between 1870 and 1918 and described how the Massachusetts Board of Health targeted towns with the highest levels of tuberculosis, including Lowell, in their publication health campaigns. The Board of Health doctors had the authority to examine mill workers for infectious disease and to inspect their working conditions; they repeatedly made a connection between respiratory illness and cotton dust (Greenlees 2005, 234). In addition to more general reforms in the towns, such as the improvement of the quality of water, they focused on the unhygienic practice of sharing a shuttle, and suction shuttles in general because they involved the weaver drawing lint and dust into their mouths (shuttle kissing) which then caused spitting. Indeed, a state inspection in 1910 stated that there was a link between tuberculosis and the practice of weavers sharing shuttles. The board also observed how the practice of humidifying the weaving and spinning rooms could facilitate the spread of tuberculosis bacteria in the spray (Greenlees 2005, 235-236). Sharing of shuttles was banned in 1911, while a report of 1912 strongly recommended the avoidance of using spray humidifiers in the interests of occupational health and that of the public at large (Greenlees 2005, 238239). The pre-teen and teenage workers in the Lowell mills lived in the era before the establishment of the Massachusetts Board of Heath in 1869 and all of these unhealthy practices may well have been a daily part of their lives. As such, it is very probable that the consumption and other lung problems identified in the death records were at least partly related to occupational practices.

\section{Conclusion}

While many Irish had left behind the horrors of the Great Famine for a new life in the United States, their experiences in Lowell during the 1840 s to 1860 s was not without its own challenges. Life in the overcrowded streets of the Acre exposed them to 
disease and ill health, including tuberculosis. Steady jobs in the mills were attractive but long working days, with practices including 'shuttle kissing' and the humidification of poorly-ventilated rooms, further facilitated the spread of consumption as well as potentially causing other respiratory diseases. The working life started young with eleven to fifteen-year-olds forming a small, but consistent, component of the workforce. The data contained within the Hanavor Burial Records is suggestive that pre-teens and teenagers had a high risk of death from tuberculosis no matter whether their jobs entailed working within a mill, as a labourer or as a housemaid. Males less than twenty years of age also appear to have engaged in occupations associated with risk, both in mills and when labouring, suggesting some gender differentiation in work-related tasks. It seems to be the case that young female workers may not have been permitted to undertake tasks perceived to have been potentially hazardous. In this study we focused on the younger workers who deaths are recorded in the Hanavor Burial Records but the fact that most workers died as young adults in their twenties and thirties serves as a reminder of the difficulties of everyday life for the Irish in mid-nineteenth century Lowell.

\section{Acknowledgements}

We are grateful to Victoria Denoon and Professor Frank Talty, co-directors of the Center for Irish Partnerships, UMASS Lowell, for their support with this research. Thanks are also due to Libby Mulqueeny, Queen's University Belfast, for preparing Figure 1. We also appreciate the insightful comments of the two anonymous reviewers which have helped us strengthen the paper.

\section{References}

Brown, R. D. 1996. The Strength of a People: The Idea of An Informed Citizenry in America, 1650-1870. London: The University of North Carolina Press.

Dickens, C. [1842] 1913. American Notes for General Circulation and Pictures from Italy. London: Chapman and Hall Ltd.

Dublin, T. 1992. Lowell: The Story of an Industrial City (Official National Park Handbook). Washington: Division of Publications National Park Service. 
Dublin, T. 1993. Women at Work: The Transformation of Work and Community in Lowell, Massachusetts, 1826-1860. New York: Columbia University Press (second edition).

Gordon, W. M. 2002. Mill Girls and Strangers: Single Women's Independent Migration in England, Scotland and the United States 1850-1881. Albany: State University of New York Press.

Green, J. O. 1873. "Autobiography of Dr John O. Green." Contributions of the Old Residents' Historical Association, Lowell Massachusetts 3: 217-242.

Greenlees, J. 2005. “'Stop Kissing and Steaming!': Tuberculosis and the Occupational Health Movement in Massachusetts and Lancashire, 1870-1918." Urban History 32: 223-246.

Kenngott, G. F. 1912. The Record of a City; A Social Survey of Lowell, Massachusetts. New York: The Macmillan Company.

Malone, P. M. 2009. Waterpower in Lowell: Engineering and Industry in NineteenthCentury America. Baltimore: The John Hopkins University Press.

Miles, H. A. 1845. Lowell, As it Was, and As it Is. Lowell: Powers and Bagley.

Mitchell, B. C. 2006. The Paddy Camps: The Irish of Lowell, 1821-61. Chicago: University of Illinois Press (paperback issue).

Roberts, C. A. and Buikstra, J. E. 2003. The Bioarchaeology of Tuberculosis: A Global View on a Reemerging Disease. Gainesville: University Press of Florida.

Robinson, H. J. 1898. Loom and Spindle: or, Life Among the Early Mill Girls; with a Sketch of 'The Lowell Offering' and some of its Contributors. Boston: T. Y. Crowell and Company. 
Whittelsey, S. 1901. "Massachusetts Labor Legislation. An Historical and Critical Study." The Annals of the American Academy of Political and Social Science 17: 1157.

\section{Murphy et al. captions}

Figure 1: Map showing the location of Lowell, Massachusetts, and its key industrial places (Prepared by Libby Mulqueeny).

Figure 2: Graph with details of female and male pre-teen and teenage age-at-death values.

Figure 3: Graph with details of female and male pre-teen and teenage occupations.

Figure 4: Graph with details of the causes of death for the female pre-teen and teenage workers.

Figure 5: Graph with details of the causes of death for the male pre-teen and teenage workers. 


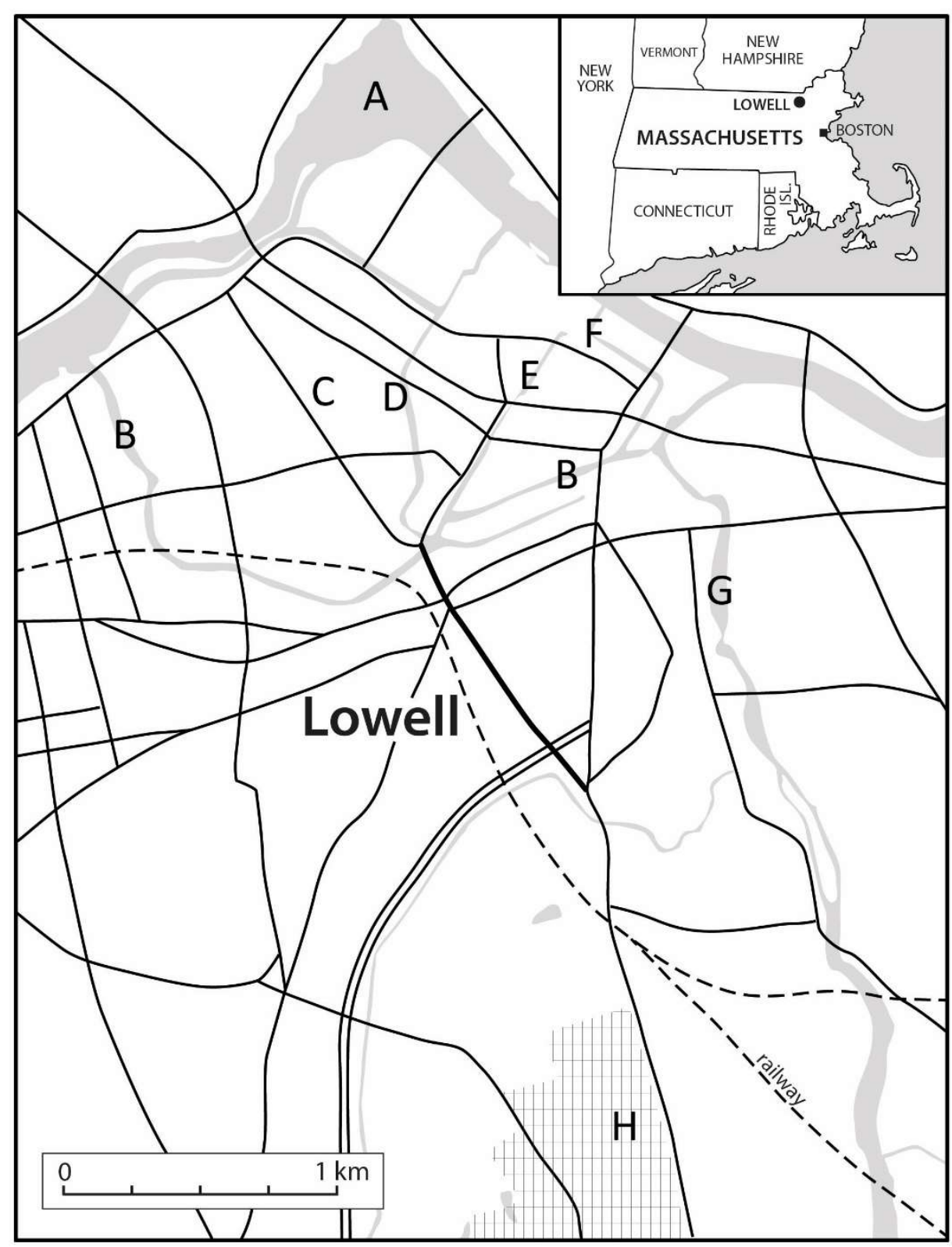

\section{LOWELL,}

MASSACHUSETTS
A: Merrimack River
B: Pawtucket Canal
C: North Commons
D: St Patrick's Church in the Acre
E: Merrimack Canal
F: Merrimack Mills
G: Concord River
$\mathrm{H}$ : St Patrick's Cemetery

Fig 1 
Age-at-Death for Pre-teens and Teenagers

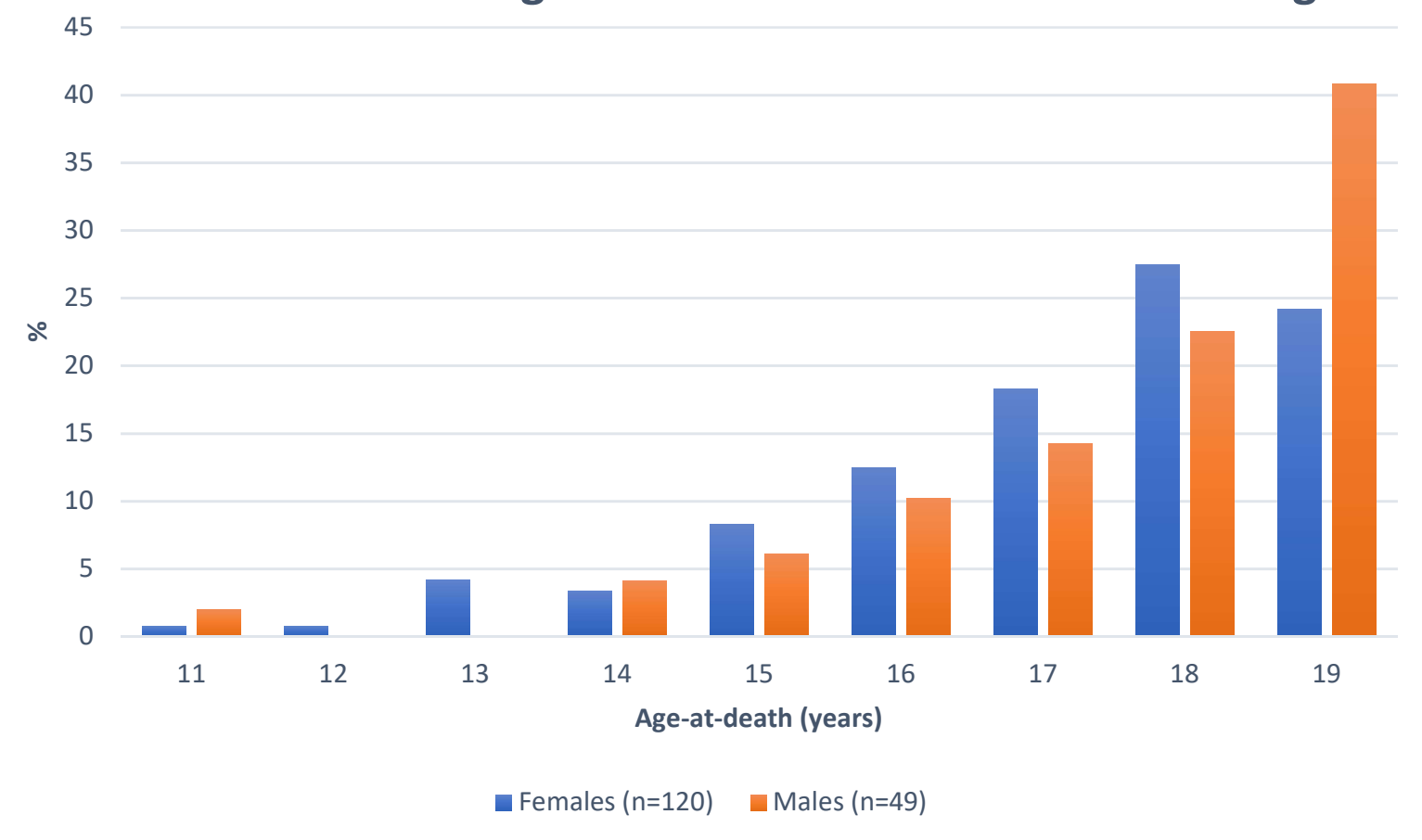

Fig 2

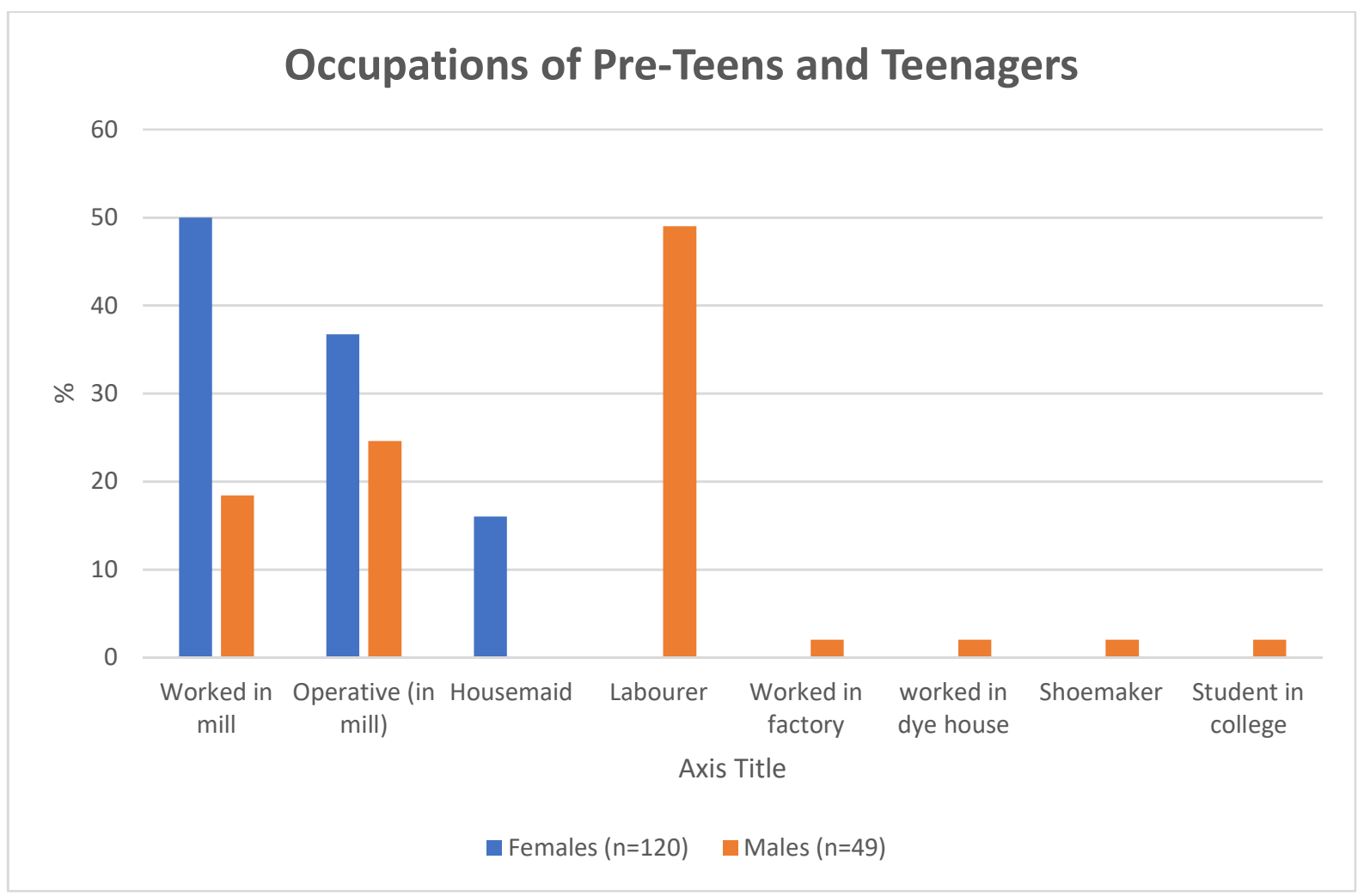

Fig 3 


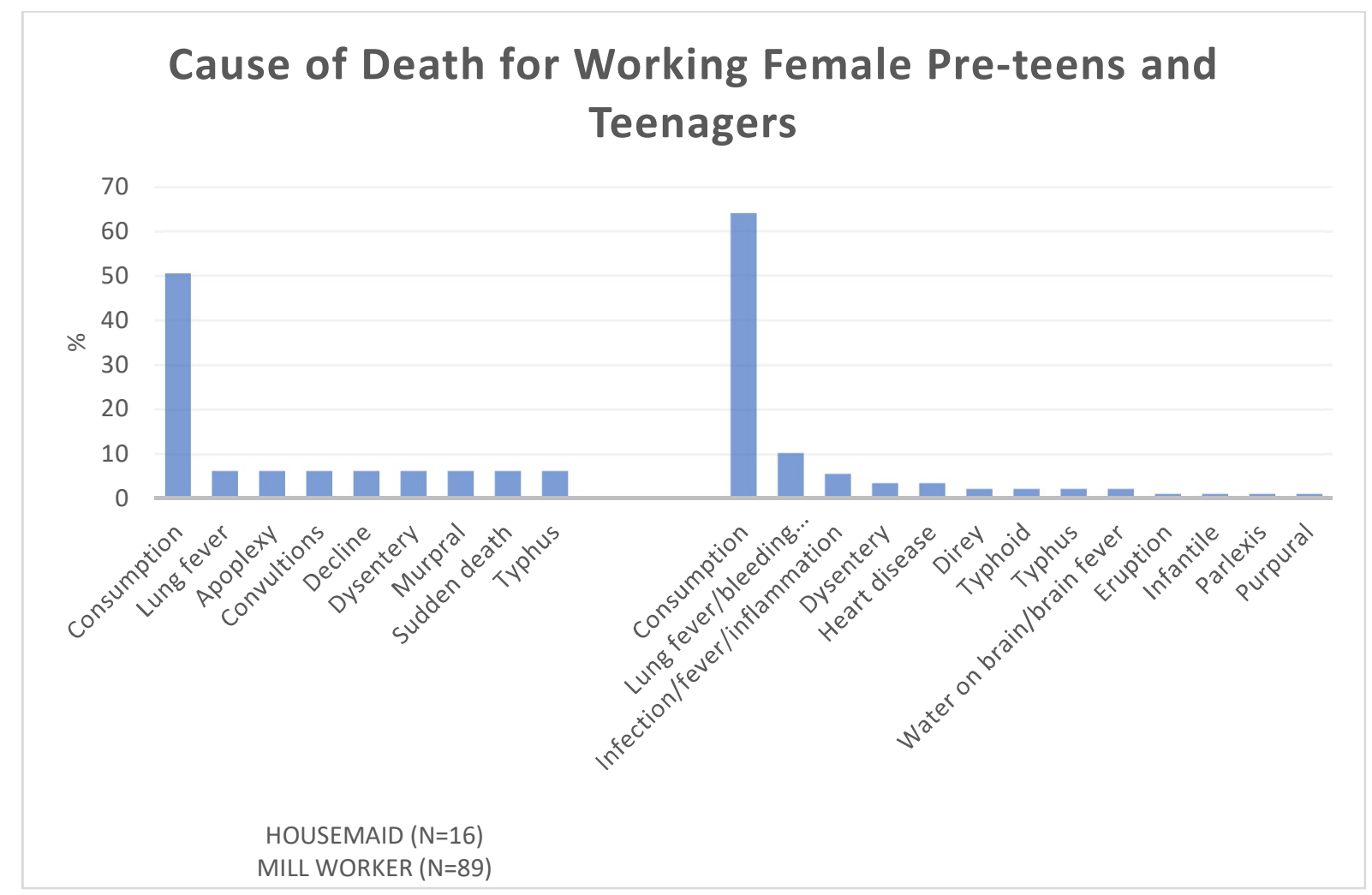

Fig 4

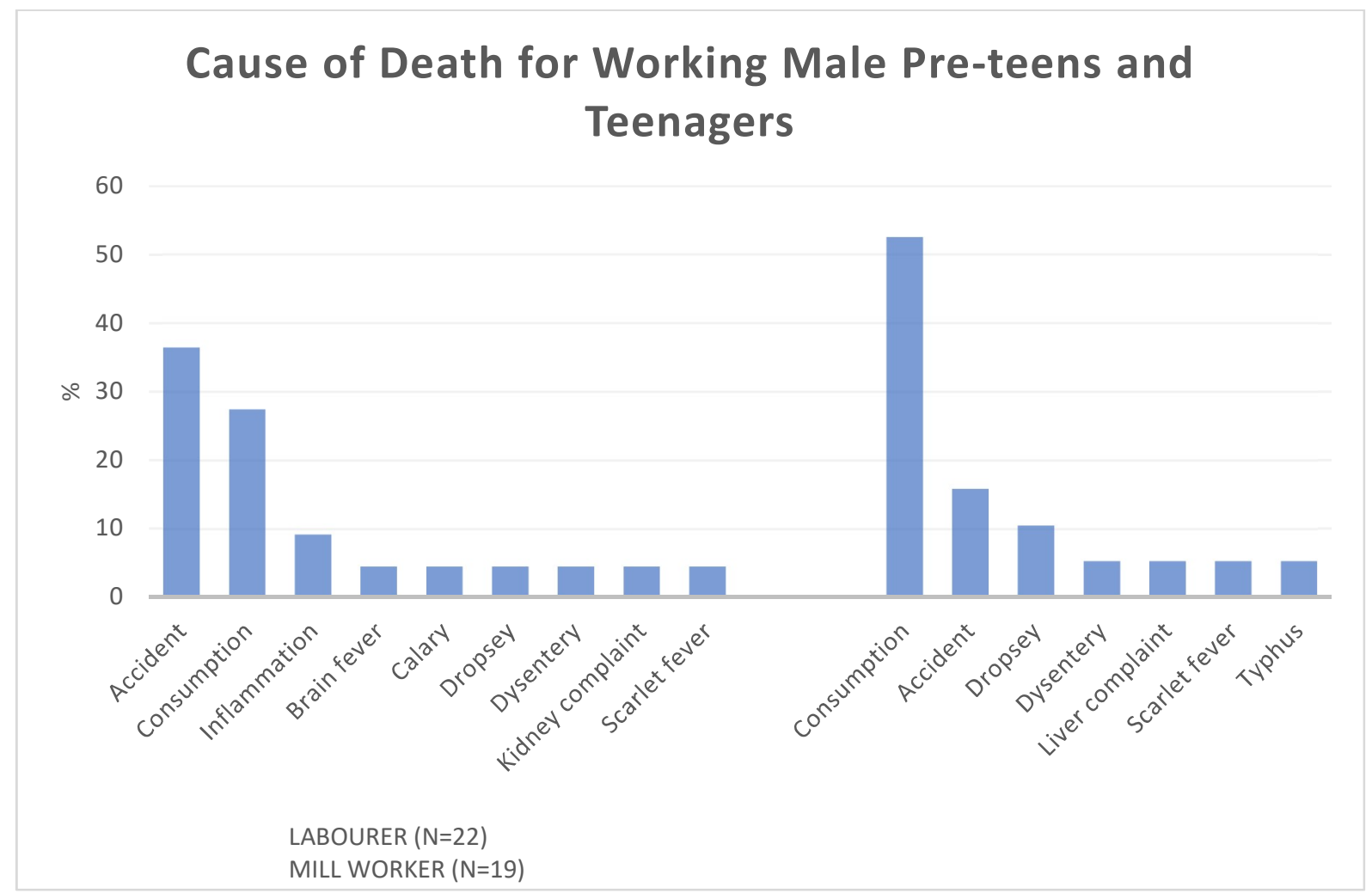

Fig 5 
Cause of Death for Working Male Pre-teens and Te $\epsilon$

60

50

40

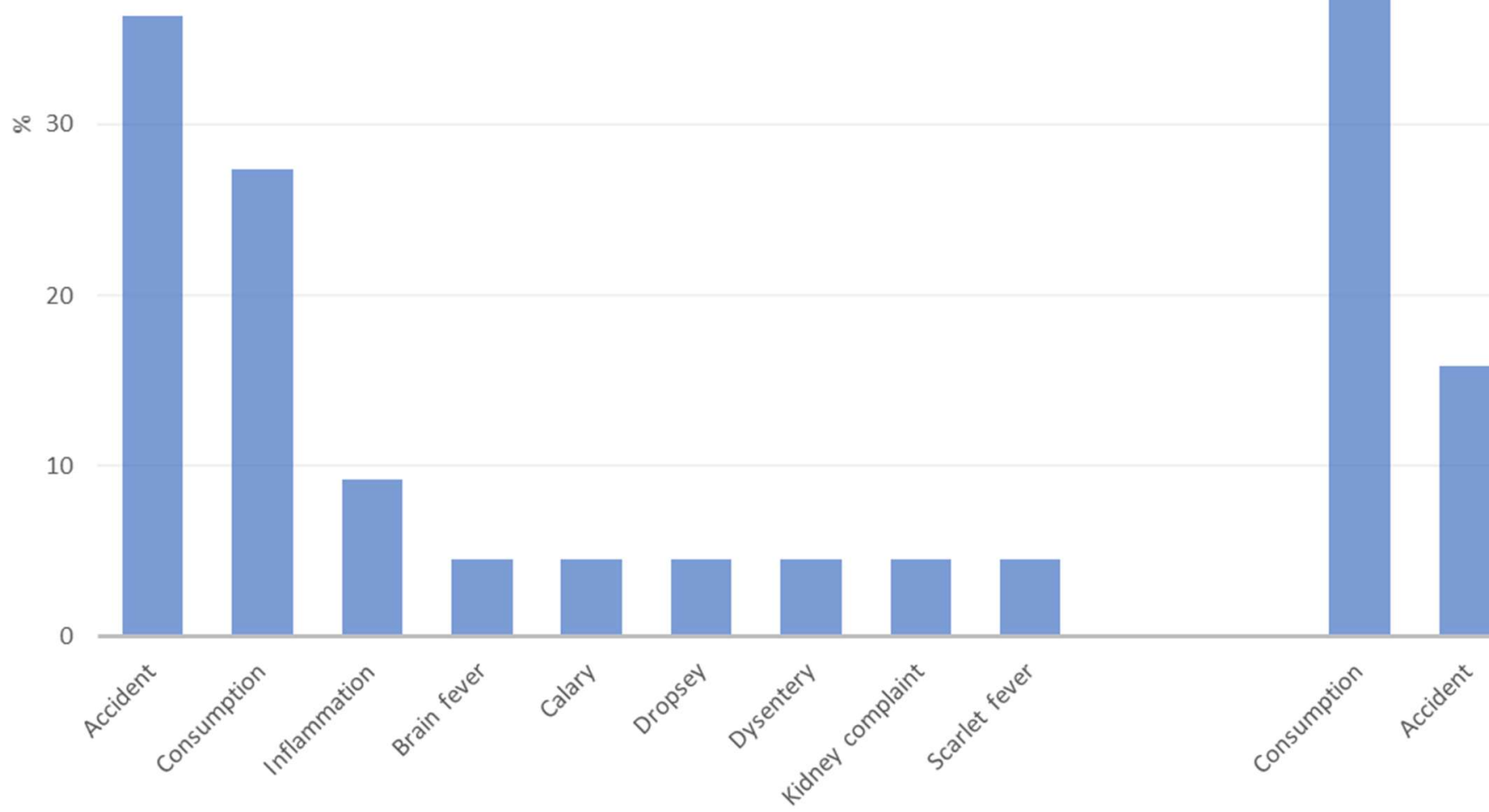

LABOURER ( $\mathrm{N}=22$ ) 